\title{
THREE NEW SPECIES OF MASDEVALLIA \\ (ORCHIDACEAE: PLEUROTHALLIDINAE) FROM THE AYACUCHO AND PUNO REGIONS IN PERU
}

\author{
STig DalströM ${ }^{1,3} \&$ SAUl Rúz PéReZ ${ }^{2}$ \\ 12304 Ringling Boulevard, unit 119, Sarasota FL 34237, U.S.A. \\ Lankester Botanical Garden, University of Costa Rica, Cartago, Costa Rica \\ National Biodiversity Centre, Serbithang, Bhutan \\ ${ }^{2}$ Allamanda 142, Surco, Lima 33, Peru \\ ${ }^{3}$ Corresponding author: stigdalstrom@gmail.com
}

\begin{abstract}
Three new species of Masdevallia, subgenus Masdevallia are described, illustrated with line drawings and color photographs, one dwarf species in section Coriaceae and two attractive and rather large species in section Masdevallia. The former section is also treated as the genus Byrsella by Luer (2006). All three new species are distinguished by unique combinations of features that separate them from all other species in the large genus Masdevallia.
\end{abstract}

Key words: New Masdevallia, Pleurothallidinae, Epidendreae, Epidendroideae, Peru

In 2006 the popular genus Masdevallia Ruíz \& Pav. had become expansive with over 500 species, classed into numerous subdivisions (Luer, 2000a, 2000b, 2001, 2002, 2003). This vast number of species, in combination with molecular investigations by various authors (Abele et al., 2005; Pridgeon \& Chase, 2001), encouraged Luer to split the genus into 16 new genera, in addition to the 4 already existing, which included Masdevallia (Luer, 2006). Although splitting large genera into smaller units may sometimes be helpful in order to make them more easily surveyed from a taxonomic point of view, the authors do not recognize the advantages of the 2006 division of Masdevallia. We find it more difficult to identify which genus many of the morphologically similar species really belong to, and believe it to be more user-friendly and practical to maintain the previous and more conservative taxonomic treatment of the genus, as circumscribed by Luer (2000a, 2000b, 2001, 2002, 2003).

\section{TAXONOMIC TREATMENT}

Masdevallia goettfertiana Dalström \& Ruíz-Pérez, $s p$. nov.

TYPE: Peru. Puno, Cerro Marrón, $2000 \mathrm{~m}, \mathrm{~S} 14^{\circ}$ 12.351'; W $69^{\circ} 13.408^{\prime}$, flowered in cultivation by Perúflora in December 2013, S. Dalström et al. 3743 (holotype: USM). Figs. 1-3.
Diagnosis. Masdevallia goettfertiana belongs to the subgenus Masdevallia, section Coriaceae which is mainly characterized by the thick leaf, the fleshy sepals, petals without any descending process, and a fleshy and verrucose lip. The dwarf plant habit with fleshy, pale glaucous leaves in combination with the fleshy flower with apically very narrow petals readily separate this species from all others in the genus.

Epiphytic herb. Plant dwarf for the subgenus, caespitose. Ramicauls erect, slender, to $c a .7 \mathrm{~mm}$ long, enclosed basally by 3 to 4 tubular sheaths. Leaf glaucous on both sides, erect to arching, coriaceous and fleshy, petiolate, blade basally conduplicate and cuneate, elliptic, obtuse, 35-55 × 7-8 mm, including the $5-15 \mathrm{~mm}$ long petiole. Inflorescence purple mottled, erect, terete, uniflowered, with a to ca. $15 \mathrm{~mm}$ long peduncle; peduncular bract 1 , basal, tubular, ca. $4.5 \mathrm{~mm}$ long; floral bract appressed, tubular, ca. $6 \mathrm{~mm}$ long; pedicel to $c a .6 \mathrm{~mm}$ long; ovary deeply sulcate, indistinctly rugose, $c a .2 .5 \mathrm{~mm}$ long. Flower shallowly cupulate and fleshy; dorsal sepal pale yellow, carinate externally, glabrous, connate to the lateral sepals for ca. 3-4 mm, then broadly acuminate and turning into an indistinct fleshy cauda, $c a .15 \times 5 \mathrm{~mm}$, including the tail; lateral sepals similar in texture, dark brown, except for the pale translucent base covered by dark purple 


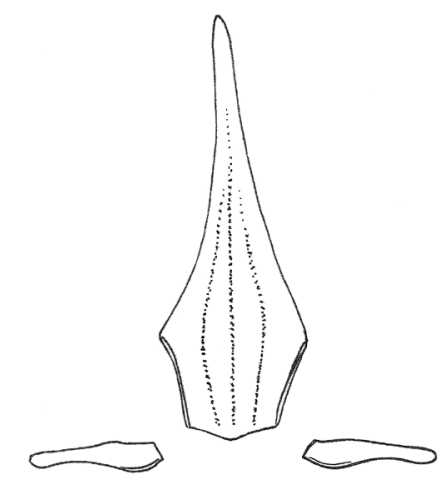

$\mathrm{E}$
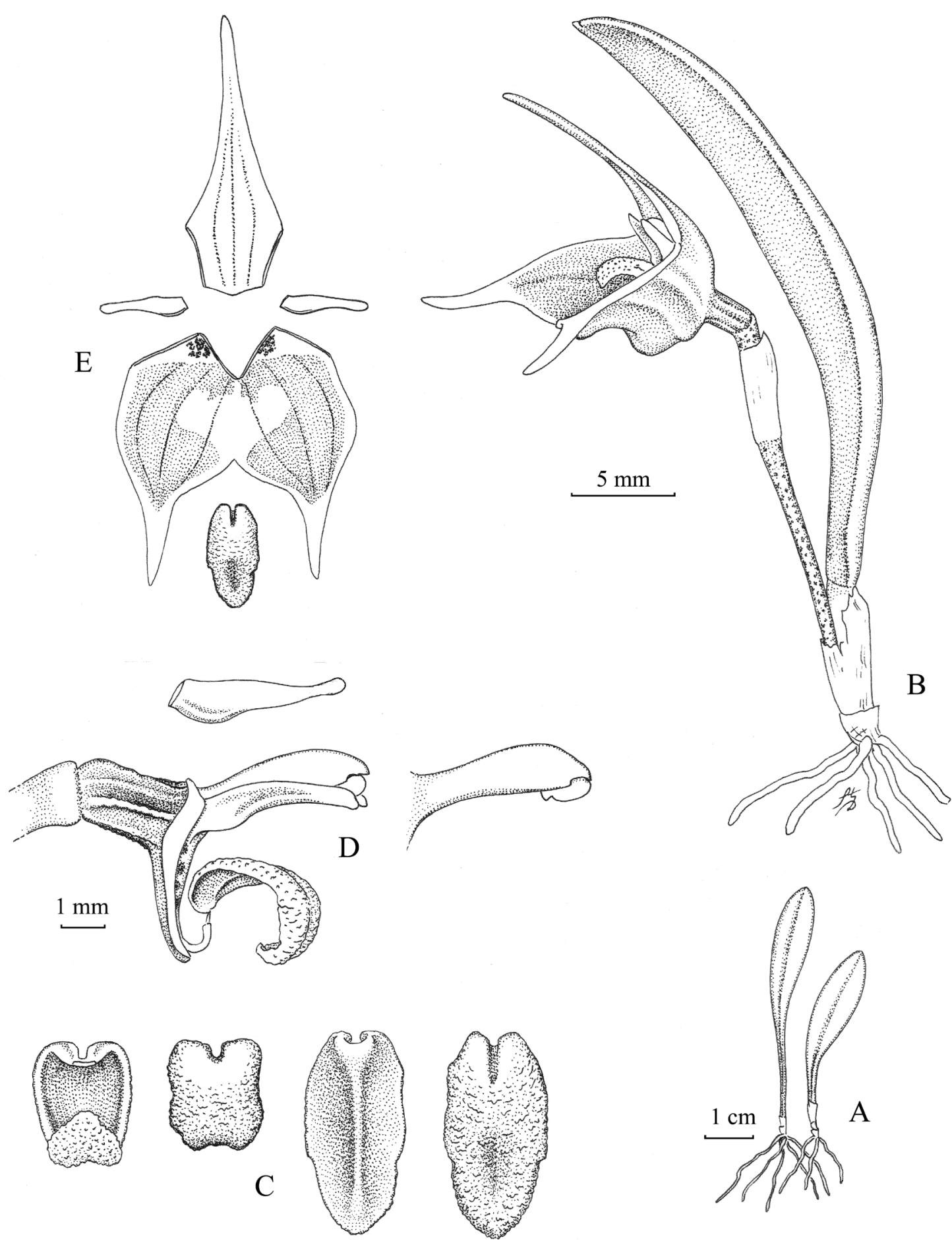

A

FIgURE 1. Masdevallia goettfertiana. A. Leaves. B. Plant habit with flower. C. Lip dorsal and ventral views in natural state and flattened. D. Column, lip and petals, lateral views. E. Dissected flower. Drawn from the holotype by Stig Dalström. 


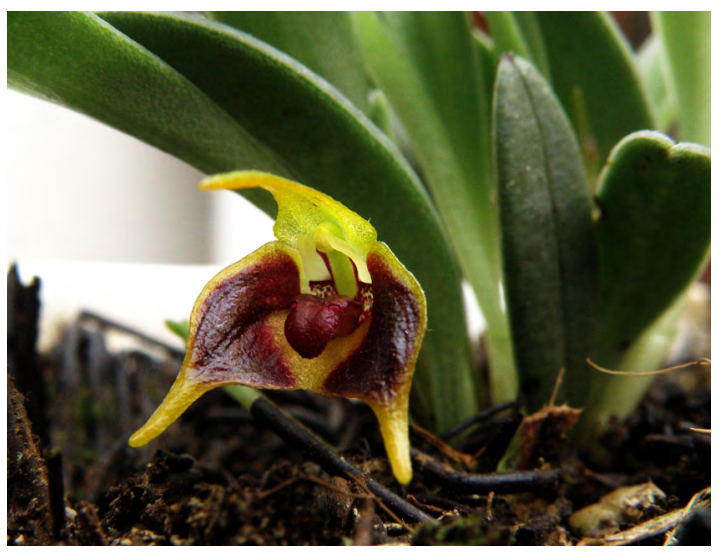

FIGURE 2. Masdevallia goettfertiana, flower in cultivation, front view. Photo of the plant that provided the holotype by S. Dalström.

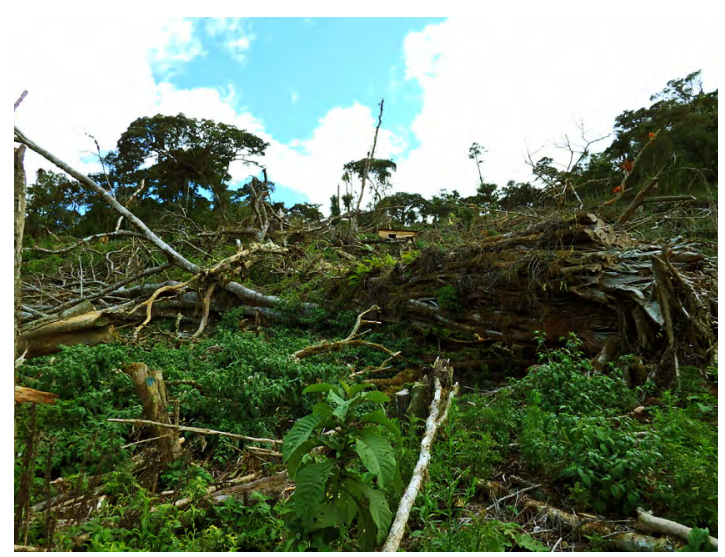

FIGURE 4. Former habitat of Masdevallia goettfertiana and many other species. Photo by S. Dalström.

spots, and the yellow indistinct and short tails, indistinctly carinate externally, ca. $12-13 \times 12-13$ $\mathrm{mm}$ combined, including the $c a .2-3 \mathrm{~mm}$ long tails, connate to each other for ca. $4-5 \mathrm{~mm}$; petals whitish, cartilaginous, obliquely and narrowly ovate and with a short fleshy, ventral keel, then with a narrow and elongate midsection with a rounded apex, $c a .4 \times 1$ $\mathrm{mm}$; lip dorsally dark purple, ventrally white, fleshy and minutely erose, hinged on the column foot by a minute strap-like tissue, lamina ovate, obtuse, with indistinct angles above the middle, carnose and sub-verrucose, basally distinctly channeled, which turns into a shallow, longitudinal groove above the middle, and with a recurved apex, $c a .4 \times 2 \mathrm{~mm}$ when flattened; column pale yellowish green with purple

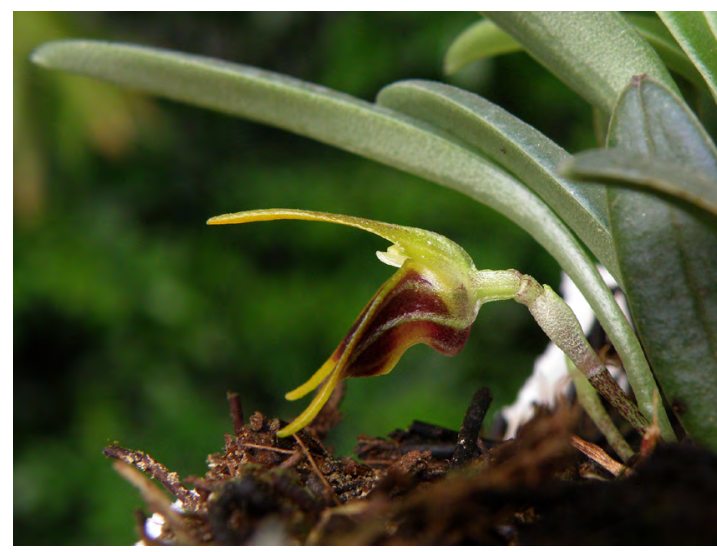

FIgURE 3. Masdevallia goettfertiana, flower in cultivation, lateral view. Photo of the plant that provided the holotype by S. Dalström.

lateral stripes, almost straight, $c a .4 .5 \mathrm{~mm}$ long, with an equally long, curved foot with a hook-shaped apex; anther cap whitish and campanulate; pollinia not seen.

The first plant of Masdevallia goettfertiana was found growing epiphytically at eye level on a dead branch along an old and well frequented trail. The habitat is characterized by secondary and very dense brush vegetation. The original plant was without any flower at the time of collection, but flowered the following year in cultivation. The dwarf plant with fleshy and glaucous leaves immediately gave rise to the notion that it probably represented something different and probably a new species. It came as a surprise, however, to realize that this small but charming orchid belongs to the section Coriaceae Rchb.f. a group of usually much larger species.

Additional material seen: Peru. Only a small population of plants has been observed in the same location as the holotype. No other collections known.

DistRiBution AND HABITAT: Masdevallia goettfertiana has only been found in a single location in scrubby and dense cloud forest on Cerro Marrón, between San Juan del Oro and Pilcopata, where the habitat is severely threatened by deforestation. Fig. 4 .

Eponymy: This species is named in honor of Peter Göttfert, of Västerås, Sweden, an avid orchid enthusiast and well known Swedish nursery man, who is also a great supporter of orchid research. 


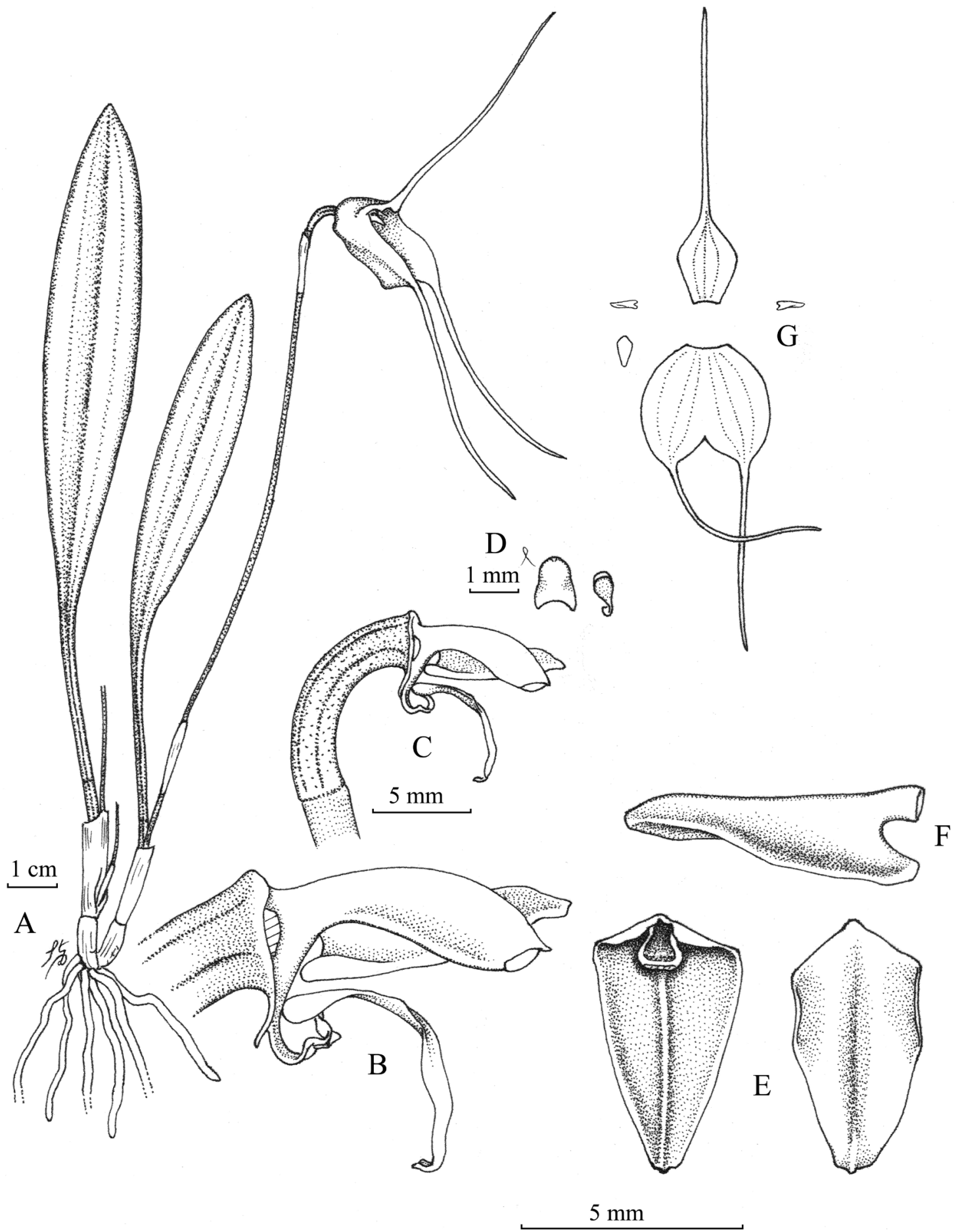

FiguRe 5. Masdevallia robineae. A. Plant habit. B. Column, lip and petal, lateral view. C. Ovary, column, lip and petal view. D. Anther cap and pollinia. E. Lip dorsal and ventral views. F. Petal internal lateral view. G. Flower dissected. Drawn from the holotype by Stig Dalström. 
Masdevallia robineae Dalström \& Ruíz-Pérez, $s p$. nov.

TYPE: Peru. Puno, east of Ollachea, Camatani, La Villa, epiphytic in mossy cloud forest at $2115-2200$ m elevation, flowered in cultivation Nov. 2014, $S$. Dalström 3774 (holotype: USM). Fig. 5.

Diagnosis. Masdevallia robineae belongs to the subgenus Masdevallia, section Masdevallia, subsection Masdevallia, and is distinguished by the white and basally pale yellow flower, with a triangular and rather flat lip with a truncate apex with an indistinct apiculum.

Lithophytic or epiphytic herb. Plant medium sized to large for the genus, caespitose. Ramicauls erect, slender, to $c a .4 \mathrm{~cm}$ long, enclosed basally by 2 or 3 tubular sheaths. Leaf erect to arching, coriaceous, petiolate, blade basally conduplicate and cuneate, elliptic, obtuse, to $c a .14 \times 2 \mathrm{~cm}$, including the $c a .4$ $\mathrm{cm}$ long petiole. Inflorescence erect, terete and slender, single flowered, with a to $c a .13 \mathrm{~cm}$ long peduncle; peduncular bracts 2 (one hidden inside basal bract), tubular, below the middle of the peduncle, to $c a .16$ mm long; floral bract appressed, tubular, to ca. 12 $\mathrm{mm}$ long; pedicel to ca. $13 \mathrm{~mm}$ long; ovary smooth, indistinctly sulcate, with scattered minute 'fungal-pits' (tiny pits where some fungi appear to establish in the wild), ca. $11 \mathrm{~mm}$ long. Flower attractive, cupulate; dorsal sepal basally pale lemon yellow and apically whitish, indistinctly carinate externally, glabrous, basally cuneate and connate to the lateral sepals for $c a .10 \mathrm{~mm}$, then obtuse and acuminate into a narrow, suberect to arching yellow tail, $c a .60 \times 12 \mathrm{~mm}$, including the ca. $45 \mathrm{~mm}$ long tail; lateral sepals similar in coloration but with pale orange basally, indistinctly carinate externally, glabrous, connate to each other for ca. $20 \mathrm{~mm}$, broadly and slightly obliquely elliptic, obtuse, acuminate with pale greenish yellow tails, $c a$. $65 \times 27 \mathrm{~mm}$ combined, including the $c a .40 \mathrm{~mm}$ long tails; petals white, cartilaginous and slightly oblique, unguiculate, with a distinct ventral lobe, extending longitudinally and ending in a fleshy ridge near the bluntly obtuse apex, $c a .7 \times 2.5 \mathrm{~mm}$; lip white, hinged on the apex of the hook-shaped column foot via a canaliculated, strap-like structure, cuneate with involute basal margins in a fresh state (cordate basally when flattened), lamina almost triangular with a bluntly truncate and minutely apiculate apex, almost flat but with a shallow longitudinal groove and indistinctly erect lateral lobes, $c a$. $5.5-6.0 \times 3 \mathrm{~mm}$ when flattened; column white with a purple base, curved downwards, ca. $6 \mathrm{~mm}$ long, with an slightly shorter, apically hookshaped foot ; anther cap white and campanulate; pollinia 2 , minute and pyriform.

Masdevallia robineae (Figs. 5-7) is an attractive species and is sympatric with the equally attractive and rare M. leonii (Fig. 8) of subsection Caudatae.

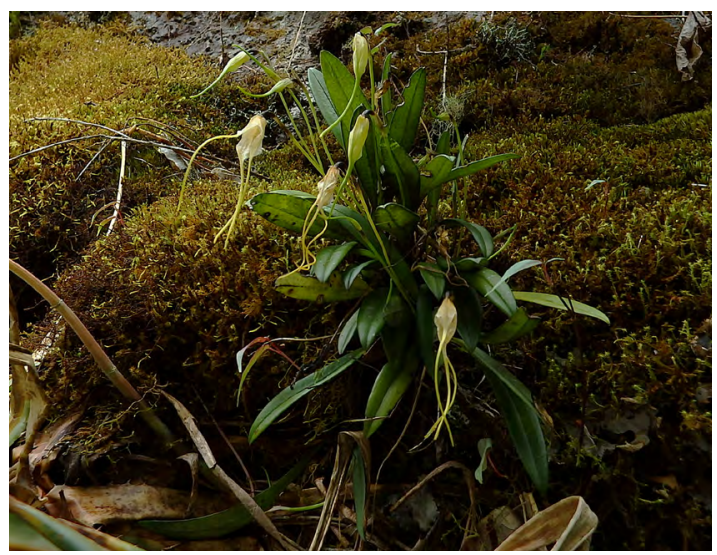

Figure 6. Masdevallia robineae. Flowering plant in natural habitat. Photo by Stig Dalström.

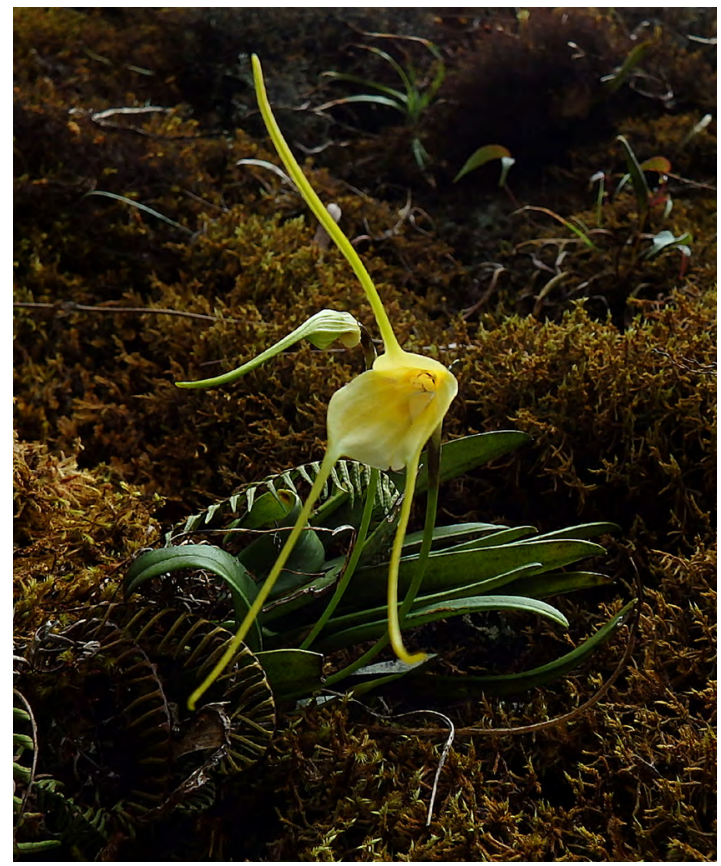

FIgURE 7. Masdevallia robineae in situ. Photo by $\mathrm{S}$. Dalström. 
Generally, the former species has a much longer leaf of a more slender shape, versus the much shorter, broadly ovate and paddle-shaped leaf of the latter species. The flowers are also quite different in shape. However, a plant with longer and slender leaves was found without flowers previous to the discovery of the type plant of M. robineae. It was believed to be something 'different' from M. leonii, which had previously been observed in flower. When the 'long-leaved' plant later flowered, however, it turned out to be a perfect M. leonii. Whether this was the result of natural hybridization or just some freak anomaly is unknown.

Additional material seen: Peru. Puno, east of Ollachea, Camatani, La Villa, lithophytic in shade on mossy boulder along the road, at $2200 \mathrm{~m}$ elevation, $\mathrm{S}$

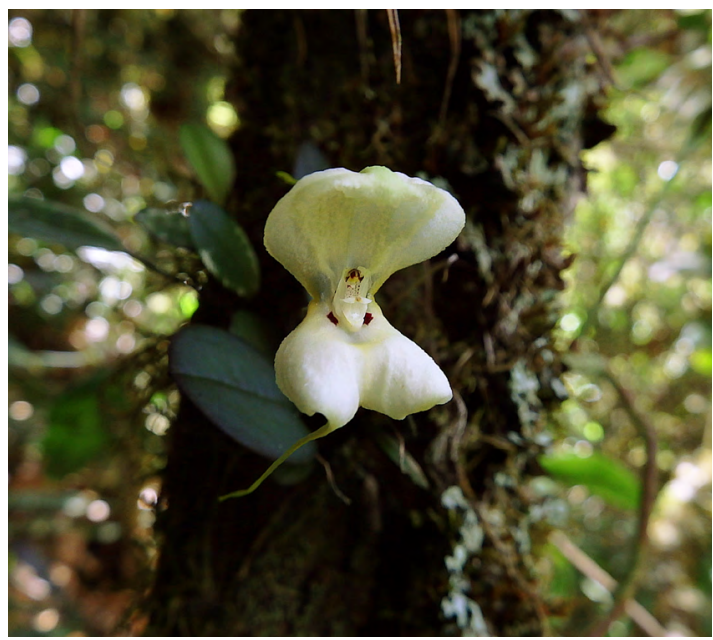

Figure 8. Masdevallia leonii in situ. Photo by S. Dalström.

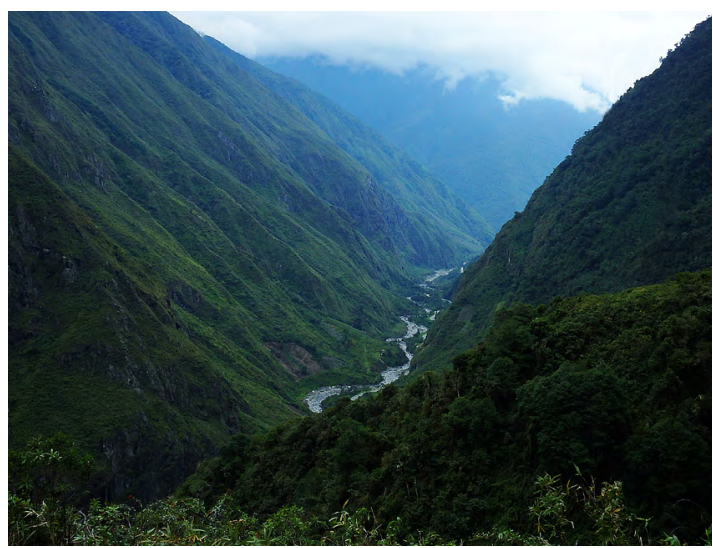

FIGURE 9. Masdevallia robineae habitat along the OllacheaSan Gaban road. Photo by S. Dalström.
013 43.832'; W 70² 27.602. Digital photo (Dalström archives). Only a few plants have been observed in the type area, growing epiphytically or lithophytically on mossy boulders. No other material seen.

Distribution AND habitat: Masdevallia robineae is only known from the steep and locally densely forested valley between Ollachea and San Gaban, Puno, at the altitude of $c a$. 2100-2200 m. Fig. 9.

Eponymy: This species is named in honor of Robine Coppens by the request of her grandfather, Guido Deburghgraeve of Liedekerke, Belgium, who discovered the type plant.

Masdevallia roseogena Dalström \& Ruíz-Pérez, sp. nov.

TYPE: Peru. Ayacucho, Calicanto, collected by a team lead by Saúl Ruíz on the ridge above the village, in wet scrubby cloud forest at ca. $2500-2600$ m elevation, 5 Dec. 2010, flowered in cultivation by Perúflora in December 2013, S. Dalström et al 3722 (holotype: USM). Figs. 10, 11.

Diagnosis. Masdevallia roseogena belongs to subgenus Masdevallia, section Masdevallia, subsection Masdevallia, and is distinguished by the attractive snowy white flowers covered by rosy magenta spots and flush on the petals and lip, and internally and externally on the lateral sepals, and with a broadly ovate, minutely apiculate lip without any visible dorsal callus.

Epiphytic or terrestrial herb. Plant medium to large for the genus, caespitose. Ramicauls erect, slender, $c a$. 3-4 cm long, enclosed basally by 3 to 4 tubular sheaths. Leaf erect to arching, coriaceous, petiolate, blade basally conduplicate and cuneate, more or less elliptic, obtuse, ca. $12.5 \times 2.5 \mathrm{~cm}$, including the $c a .4 \mathrm{~cm}$ long petiole. Inflorescence erect, terete and slender, single-flowered, with a to $c a$. $10 \mathrm{~cm}$ long peduncle; peduncular bracts 2 , tubular, below the middle of the peduncle, to $c a .1 \mathrm{~cm}$ long; floral bracts appressed, tubular, to $c a .1 .2 \mathrm{~cm}$ long; pedicel to $c a .2 .5 \mathrm{~cm}$ long; ovary smooth and indistinctly sulcate, with scattered minute 'fungal-pits', ca. $6 \mathrm{~mm}$ long. Flower attractive, cupulate; dorsal sepal snowy white with rose-magenta flush externally and richly spotted internally, glabrous and carinate externally, 

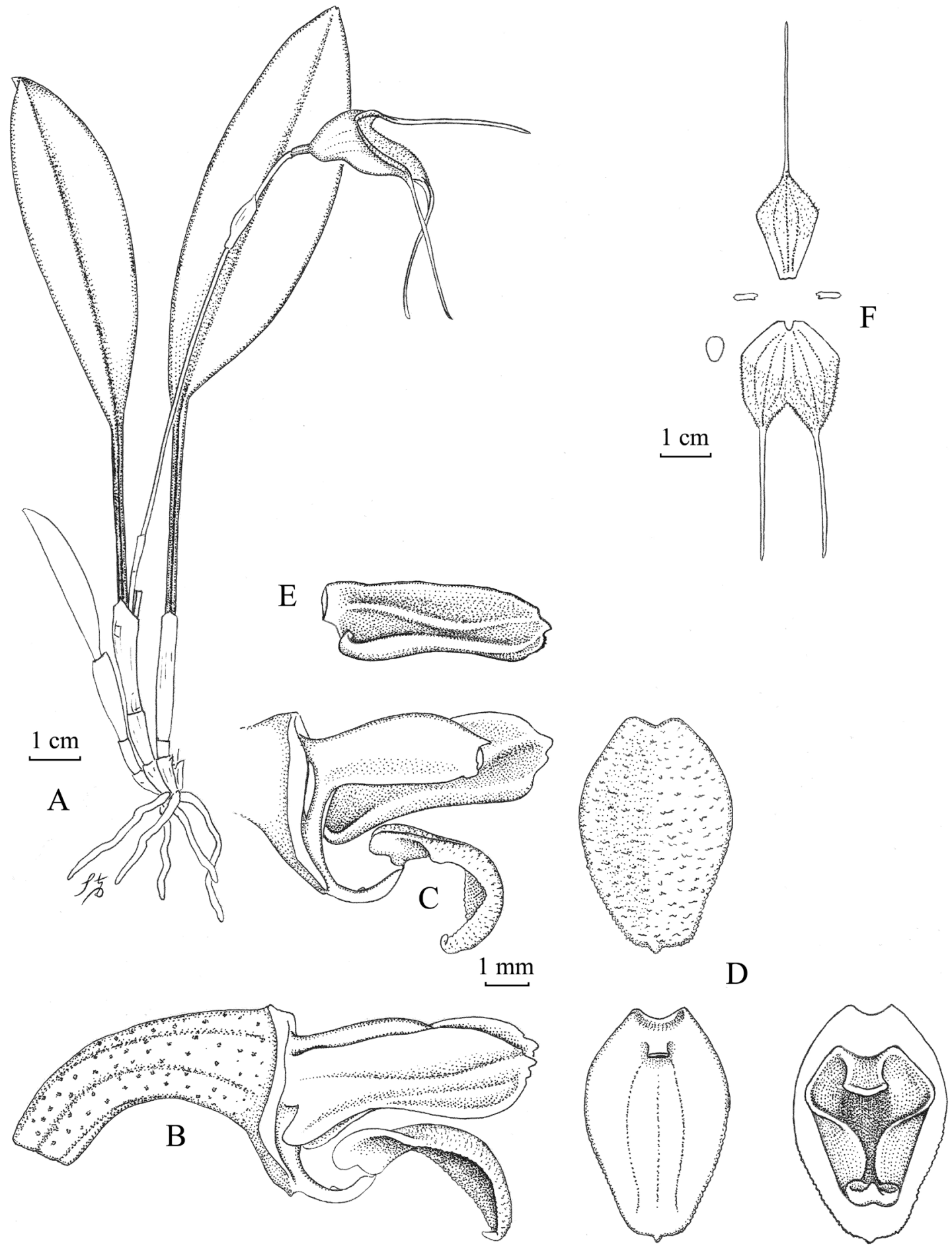

Figure 10. Masdevallia roseogena. A. Plant habit. B. Ovary, column, lip and petals, lateral view. C. Column, lip and petal lateral view. D. Lip dorsal and ventral views (flattened and in natural state). E. Petal internal lateral view. F. Flower dissected. Drawn from the holotype by Stig Dalström. 


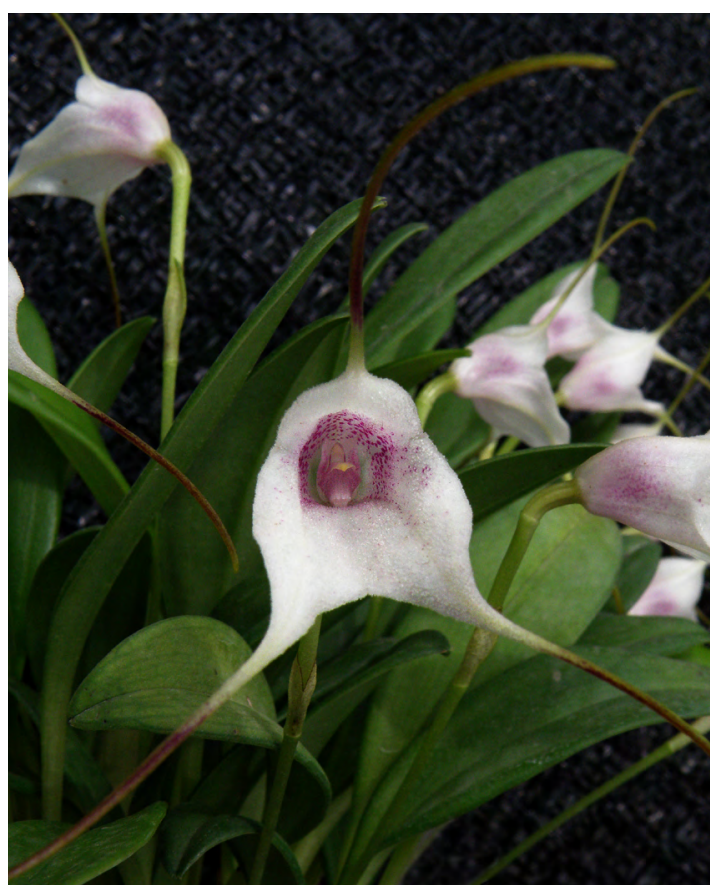

FiguRE 11. Masdevallia roseogena, flowered in cultivation by Perúflora. Photo by S. Dalström.

densely microscopically glandular internally, connate to the lateral sepals for ca. $13-15 \mathrm{~mm}$, then acute and apically extended into an elongate and narrow tail, ca. 13 $\times 50 \mathrm{~mm}$, including the $30 \mathrm{~mm}$ long, basally white, then purple, gradually turning olive green tail; lateral sepals similar in texture and coloration, glabrous and carinate externally, microscopically glandular internally, connate for $c a .15 \mathrm{~mm}$, then slightly and obliquely obtuse, extending in a slender tail, ca. $50 \times 20 \mathrm{~mm}$ combined, including the $c a .25 \mathrm{~mm}$ long tails; petals white with rose-magenta markings, cartilaginous and slightly oblique, indistinctly unguiculate with a distinct, curved lateral lobe, forming a fleshy, longitudinal ridge ending near the truncate and apiculate apex, $c a .5 .5 \times 2 \mathrm{~mm}$; lip white suffused with rose-magenta and a pale yellow apex, hinged on the hook-shaped column foot via a minute strap-like structure, lamina ovate, minutely subverrucose dorsally, obtuse and apiculate when flattened, but revolute and ventrally concave in the natural state, with a shallow notch at the base, ca.4.5-5.0 $\times 3.2-3.5$ $\mathrm{mm}$ when flattened; column white with purple edges, straight, $c a .4 \mathrm{~mm}$ long, with an equally long, curved, apically hook-shaped foot ; anther cap white and campanulate; pollinia not seen.

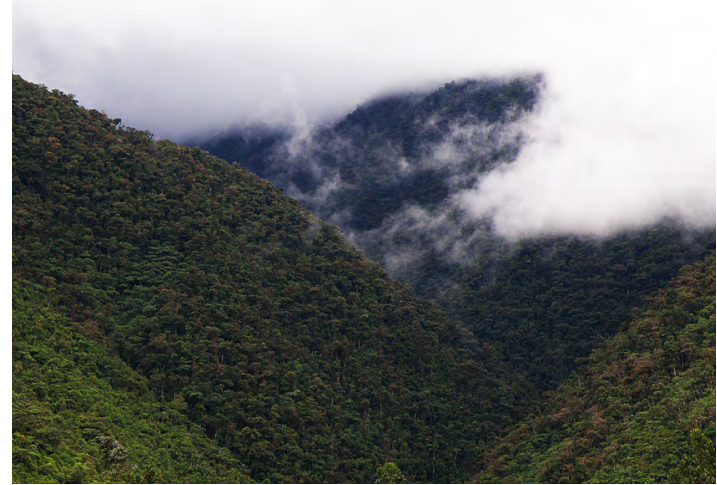

FIgURE 12. Masdevallia roseogena habitat in the Ayacucho region. Photo by S. Dalström.

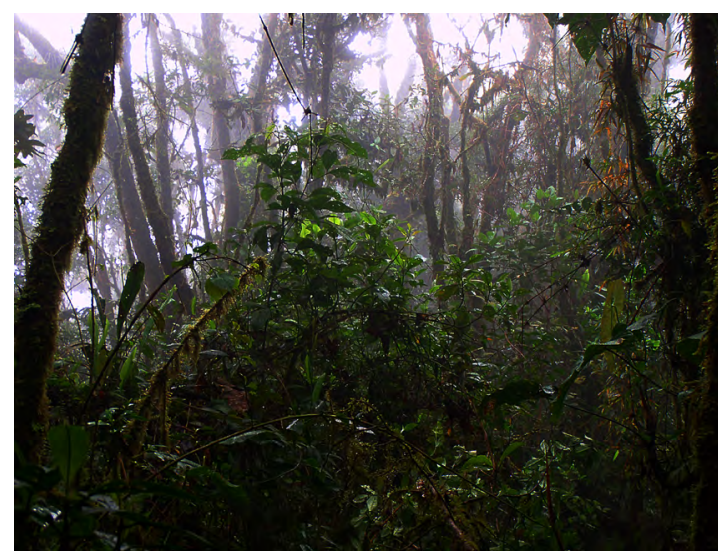

FIgURE 13. Masdevallia roseogena habitat in the Ayacucho region. Photo by S. Ruíz.

Additional material seen: Peru. Only a few scattered plants have been discovered in the same area as the holotype. No other collections known. This region is subject to intense deforestation and habitat destruction, particularly at higher elevations.

Distribution AND HABITAT: Masdevallia roseogena has only been found in a single location along the densely forested ridge above the village of Calicanto, Ayacucho. Figs. 12, 13.

Eтymology: This species is named in reference to the white flowers with a rosy 'blush' on the lateral sides of the sepals (the 'cheeks'); Latin for rosy-red producing, and 'gena' referring to the cheeks.

Masdevallia roseogena was originally discovered by a team lead by Saúl Ruíz in extremely wet and dense, scrubby cloud forest along the ridge above 
the small town of Calicanto in the Ayacucho region. This is a dangerous area, teeming with military presence and subject to occasional violence by the Shining Path movement. This in turn renders the local population extremely suspicious of foreigners and their whereabouts.
ACKNOWLEDGMENTS: We thank the staff at the Instituto Recursos Naturales (INRENA), and Betty Millán and Ricardo Fernández at the Universidad de San Marcos, Museo de Historia Natural, Lima, for providing assistance. We also thank Wesley Higgins for commenting on the manuscript, Manolo Arias Silva and his family and staff of Perúflora for logistic support and hospitality, and Steven Beckendorf, Guido Deburghgraeve, Jan Sönnemark, Howard Liebman and others for stimulating and helpful company in the field.

\section{LiTERATURE CITED}

Abele, C., Rudolph, B., Thiede, J. \& Rohwer, J. G. (2005). Phylogeny of the genus Masdevallia Ruíz \& Pav., based on morphological an molecular data. Proceedings of the $18^{\text {th }}$ World Orchid Conference, Dijon, France, 111-115.

Luer, C. A. (2000a). Icones Pleurothallidinarum XIX. Systematics of Masdevallia part one. Monogr. Syst. Bot. Missouri Bot. Gard., 77, 1-264.

Luer, C. A. (2000b). Icones Pleurothallidinarum XXI. Systematics of Masdevallia part two. Monogr. Syst. Bot. Missouri Bot. Gard., 82, 265-518.

Luer, C. A. (2001). Icones Pleurothallidinarum XXII. Systematics of Masdevallia part three. Monogr. Syst. Bot. Missouri Bot. Gard., 86, 510-780.

Luer, C. A. (2002). Icones Pleurothallidinarum XXIII. Systematics of Masdevallia part four. Monogr. Syst. Bot. Missouri Bot. Gard., 87, 781-1047.

Luer, C. A. (2003). Icones Pleurothallidinarum XXV. Systematics of Masdevallia part five. Monogr. Syst. Bot. Missouri Bot. Gard., 91, 1049-1293.

Luer, C. A. (2006). Icones Pleurothallidinarum XXVIII. A reconsideration of Masdevallia, Systematics of Specklinia and vegetatively similar taxa (Orchidaceae). Monogr. Syst. Bot. Missouri Bot. Gard., 105.

Pridgeon, A. M. \& Chase, M. W. (2001). A phylogenetic reclassification of Pleurothallidinae. Lindleyana, 16(4), 235-271. 